\title{
Review
}

\section{Innovation and European Energy Industry Sustainability in growth, efficiency, and effectiveness}

\author{
Muslima Zahan, Ph.D \\ Assistant Professor (Adjunct Faculty), Faculty of Business Studies, Bangladesh University of Professionals, Dhaka, \\ Bangladesh
}

Author email address: muslima.zahan@gmail.com

ABSTRACT

\begin{abstract}
The sources of environmental problems were acknowledged to stem from industrialization and the ever-increasing consumption of materials and energy (Ashford et al., 2012). In the meantime, the fossil fuels are being replaced by renewable energy from home to industry worldwide. Thus, technological evolutions and environmental concerns are two of the macro-environmental factors to the European energy industry (Xerfi Global, 2009). The first one is of positive while the second one is very negatively influential. The financial crisis and the subsequent lack of credit availability lead the European Energy operators to redefine their strategy. Along, increasing concern regarding climate change has led to adopt EU Emissions Trading System (EU ETS); the Member states are bound to reach some targets. Therefore, this script presents the vision of conceptualizing sustainability in the European energy industry exploring the view of growth, efficiency and effectiveness from different literature.
\end{abstract}

Keywords: environmental problems, Industrialization, Technological evolutions, Emissions Trading System

\section{INTRODUCTION}

Sustainable development that 'meets the needs of the present without compromising the ability of future generations to meet their own needs'. In industrial terms this means growing industry while keeping the environmental, and also the social and economic, impacts at a sustainable level (European Commission, 2011). However, a sustainable energy economy requires commitments to both renewable and efficiency. Renewable energy and energy efficiency are the twin pillars of sustainable energy policy. Efficiency is essential to slowing the energy demand growth so that rising clean energy supplies can make deep cuts in fossil fuel use. Any serious vision of a sustainable energy economy thus requires major commitments to both efficiency and renewable (Prindle B and Eldridge $M$, 2007).

$81 \%$ of CEO's in the energy industry see climate change as the global development issue most critical to address for the future success of their business as well as $91 \%$ report that their company will employ new technologies to address sustainability issues over the next five years. Energy CEO's belief in the importance of sustainability is stronger than ever (figure1), in spite of the recent economic downturn (Hanna $A$ and Lacy $P$, 2011). So, the innovation of new technology; for example renewable energy and its access of it can play important role to sustain the industrial development of the European energy industry.

This is open secret about the battle for gas supply and value chain control between European Union and Russia. $20 \%$ of EU electricity is generated from natural gas and the share of Russian gas in total European gas supply is expected to reach $50 \%$ in 2030 . Other than this, the legal environmental bindings pursue to cut greenhouse gas emissions by $20 \%$, to establish a $20 \%$ share for renewable energy, and to improve energy efficiency by $20 \%$ (Xerfi Global, 2009). Technological innovations; Concentrated Solar Power (CSP) should be important drivers for the economic growth of Europe and its efficient use enable the modern economy to sustain its development against global resource scarcity and competition. Therefore, the first goal is learn about the current industrial energy efficiency, technological status of CSP, the initiatives to access the solar power and its upcoming contribution to the industrial growth; specially the sustainable growth of energy economies. Otherwise 


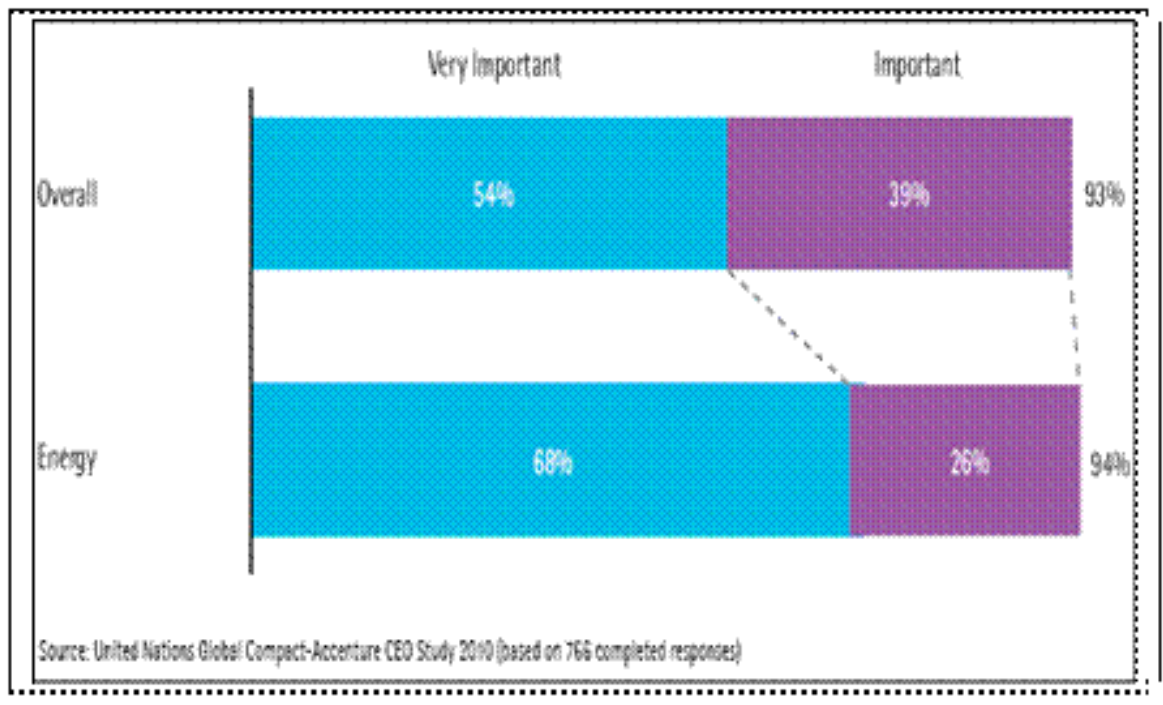

Figure1. How important are sustainability issues to the future success of your business? (Respondents answering 'Important' to 'Very Important').

Source: Hanna and Lacy, 2011

the technology is not alone enough to make the industrial system sustainable and the industrial system should be (Evans et al., 2009). This can be done for growth, efficiency and effectiveness of the energy use.

Several valuable studies dealt with energy industry, Mediterranean energy sources and European economies are identified. The much referred study of Twin Pillars of Sustainable Energy (Prindle $B$ and Eldridge $M$, 2007) discussed the synergies between efficiency and renewable; economic synergies provide price stability benefits and complementary economic development by generating investments and employments. An integrated EUMENA (European Union, Middle East and North africa) power system allows Europe to meet its $\mathrm{CO}_{2}$ reduction targets in the power sector more effectively and more economically by importing its electricity demand from the MENA region. The study of Dii (2012) shows why and how and interconnected, renewables-based power system for EUMENA is valuable for reasons of competiveness, sustainability and security of supply. The very related study of Pansini, 2012 (Doctoral Fellowship Study, Sustainable Science Program, KSG, Harvard) focuses the need to sustain market development of clean energy technologies for European and south-eastern Mediterranean countries. The European Union needs to strengthen energy cooperation with neighbouring regions in order to share energy sources and infrastructures. The testcase of the impact of grid connection between Italy and Tunisia is a good point of CSP access to European territory through Italy. The study of Sara and Stenzel (SolarPACES, 2012) focuses on the grid integration from Tunisia to European Market, which allows commercially viable enterprise to be developed. Similar way, the study of Witton (2010) refers the submarine connection of solar power export to EU is undoubtedly attractive. It finds that access to capital is required to drive urgently needed infrastructure investment. Except energy industry, competitiveness is studied in the study of Rademaekers et al., 2011 (p9-10). So, it is time to focus on European energy industry sustainability with the access of concentrated solar energy from Mediterranean.

Decoupling should be the key indicator of positive trends in sustainability and efficiency. Two types of decoupling can be considered: Relative Decoupling and Absolute Decoupling. The EC (European Commission, 2011) study defines Relative decoupling of impacts from economic activity occurs when, relative to changes in economic activity, impacts change at a proportionally slower rate-the intensity of use falling, relative to the quantity of output produced. On the other hand, Absolute decoupling of impacts from economic activity occurs when not only does the intensity of the use of resources fall relative to increasing output but, this fall is sufficient to reduce the overall quantity of resources used (Figure 2). Thus, analyses include weakening the link between an increase in GDP (Gross Domestic Product) or GVA (Gross Value Added) and an increase in GHG (Greenhouse Gas) emissions, or the link between increasing industrial output and increasing resource inputs. Thus growth and resource efficiency (energy efficiency focused) should be a good indicator in understanding the sustainable development of European energy industry.

The industrial input and output scenario can also be used to measure efficiency being studied in the book 'Energy Consumption in the Manufacturing Industry in South Asia (Zahan, M, 2013). Efficiency can also be measured with the proposed non-parametric approach (Andriosopoulos et al., 2012) based on the data support. Effectiveness can be addressed through the capital 


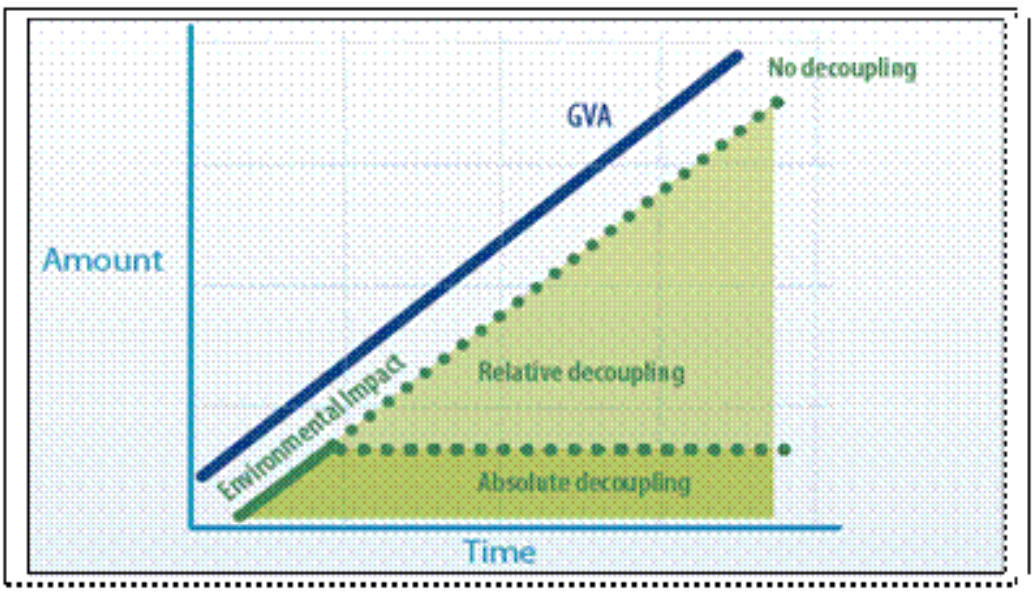

Figure2. Absolute and Relative decoupling.

Source: Ecorys, EC, 2011

investment to energy efficiency as well as capital investment to Mediterranean countries for sustainable energy source to Europe. Sustainable development criteria can also be verified for European energy industry as conducted in the study of Zahan et al., 2012.

\section{CONCLUSION}

The key indicator; decoupling could be the benchmark for effective management and strategies as well as to understand economic growth and environmental impacts. The macro level SWOT (Strength, Weakness, Opportunity and Threat), review of the classic economic literature on related matters (theoretical framework, investment decision drivers, EU emissions trading Policy etc.) can also be valuable study matters to follow up.

The current status of European energy industry and indication would enable to sort the development criteria for the sustainability. The analysis of access of CSP to Europe explores whether it is a threat or opportunity for the future development of this industry. The energy efficiency indicators could direct toward more import of gas and electricity, or investment for efficiency or sound competitiveness among the industry players. European emissions trading through Clean Development Mechanism (CDM) or Joint Initiatives (JI) can be successfully exploited with the entry of CSP that ultimately play strong role to the sustainable development of the energy industry. Finally the access of CSP to Europe and view of growth, efficiency and effectiveness could be valuable benchmark to for the sustainable development of energy industry sustainability and achieve strategic view.

\section{REFERENCES}

Ashford NA, Hall RP, Ashford R (2012). Addressing the Crisis in Employment and Consumer Demand: Reconciliation with Environmental and Financial Sustainability. The European Financial Review, Sustainability Section.
Xerfi Global (2009). Energy Groups in Europe-Market AnalysisCorporate Strategies.

European Commission (2011). Sustainable Industry: Going for Growth and Resource Efficiency, ECORYS Netherlands BV

Prindle B, Eldridge M (2007). The Twin Pillars of Sustainable Energy: Synergies between Energy Efficiency and Renewable Energy Technology and Policy, American Council for an Energy-Efficient Economy. ACEEE Report Number E074

Hanna A, Lacy P (2011). Towards a New Era of Sustainability in the Energy Industry, United Nations Global Compact-Accenture CEO Study

Xerfi Global (2009). Energy Groups in Europe-Market AnalysisCorporate Strategies, August

Evans S, Bergendahl M, Gregory M, Ryan C (2009). Towards a sustainable industrial system: accelerating the contribution of education and research, University of Cambridge.

Prindle B, Eldridge M (2007). The Twin Pillars of Sustainable Energy: Synergies between Energy Efficiency and Renewable Energy Technology and Policy, American Council for an Energy-Efficient Economy. ACEEE Report Number E074.

Dii Desert Power 2050 (2012). Perspective on a Sustainable Power System for EUMENA.

Pansini A (2012-13). The role of renewable energy sources towards the establishment of a Euro-Mediterranean energy co-operation partnership, Giorgio Ruffolo Research Fellow in the Sustainability Science Program. Internet sources: http://www.hks.harvard.edu/centers/mrcbg/programs/sustsci/peopl e/research-fellows/current-fellows/annalidia- pansini

SolarPACES (2012). Concentrating Solar Power and Chemical Energy System, Book of Abstract, Marrakesh, Morocco.

Witton T (2010). Can Algeria be a stable and sustainable source of energy for Europe?, Mediterranean Paper Series. The German Marshall Fund of the United States.

Rademaekers K, Asaad S, Berg J (2011), Study on the competiveness of the European Companies and Resource Efficiency, Ecorys, Final Report

European Commission (2011). Sustainable Industry: Going for Growth and Resource Efficiency, ECORYS Netherlands BV

Zahan M (2013). Book: Energy Consumption in the Manufacturing Industry in South Asia, LAP Lambert Academic Publishing, Saarbruecken, Germany, Chapter 2.

Andriosopoulos K, Makridou G, Doumpos M, Zouponidus C (2012). An integrated approach for energy efficiency analysis in European Union countries, Working Paper, ESCP Europe, London.

Zahan M, Sarker T, Corradetti R (2012). Policy and Projects: Reduction of Carbon Emissions in the Manufacturing Industry in South Asia, J. Econ. Sustainable Develop. 3(14): 98-109.

How to cite this article: Muslima Zahan, Ph.D (2015). Innovation and European Energy Industry Sustainability in growth, efficiency, and effectiveness. J. Res. Econ. Int. Finance 4(1):19-21 